\title{
ARTICLE
}

\section{The result of the study on feeding Young pigs with mineral premixed feed}

\author{
Sangajav Dorjpurev*1, Otgonjargal Ayushjav ${ }^{2}$ and Togtokhbayar Norovsambuu ${ }^{2}$ \\ ${ }^{1}$ Feed evalution laboratory, Research Institute of Animal husbandry, \\ Ulaanbaatar, Mongolia \\ ${ }^{2}$ School of Animal Science \& Biotechnology, Mongolian University of Life Sciences, \\ Ulaanbaatar, Mongolia
}

ARTICLE INFO: Received: 01 Feb, 2021; Accepted: 9 Aug, 2021

\begin{abstract}
We have conducted study on the impact on productivity when young pigs are fed with premixed full-formula feed. Based on the daily nutrient requirements for young pigs, we prepared 6 recipes, and fed 60 Landras pigs for 60 days. According to the results of the study, protein and mineral added recipes (recipes 1 and 5) for young pigs increase the daily weight gain by 34.5-39.2 per cent. Live nutrient weight and slaughter output are directly affected by feed nutrition, recipe digestion, and exchange energy amount.
\end{abstract}

Keywords: Chemical composition of the recipe; daily weight gain;

\section{INTRODUCTION}

In order to intensify pig farming in Mongolia, increase pork production, and reduce pork imports, we have to create a reliable fodder base and towards this end, it is important to increase domestic production of full-formula mixed feed for pigs. This would also guarantee food safety provided the country produces more than 70 per cent of its food consumption. Also, if a nation imports more than 20 per cent of food from another country then that country is classified as food dependent. [2].

Today, Mongolia produces only 25 per cent of its pork consumption, and the remaining 75 per cent is imported from China, Poland, Hungary, Germany and South Korea [3].
This necessitates finding ways to optimize the use of fodder and one option is the use of exogenous enzymes to assist with digestion [7].

Mixed ration, hay, silages, concentrates, supplements or premix, which help improve the digestion quality of pig feed, also help increase the availability of nutrients in the cell wall [8].

This status of the importing of pig feed and pork from foreign markets may pose serious danger to the food security of the population, and the fact that Mongolian pig farming is directly dependent on foreign countries $^{1}$, the General Customs Administration is a potential obstacle to pig farming development.

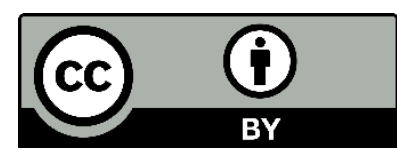

The Author(s). 2021 Open access This article is distributed under the terms of the Creative Commons Attribution 4.0 International License (https://creativecommons.org/licenses/by/4.0/), which permits unrestricted use, distribution, and reproduction in any medium, provided you give appropriate credit to the original author(s) and the source, provide a link to the Creative Commons license, and indicate if changes were made. 
Therefore, it is important to study the possibilities of producing pig feed in the country and improving its quality using domestic raw materials. [5].

In view of this, the objectivee of this study is to develop a full-formula mixed feed

\section{MATERIALS AND METHODS}

60 Landras young pigs were selected for the experiment. They were tested for 60 days with mixed feed. There were ten 3-month-old pigs with an average weight of $40 \pm 2.1 \mathrm{~kg}$, which were put in one group and fed. A total of 6 recipes were developed and tested in 5 experiments and 1 control group for mixed feed experiments for young pigs.

The chemical composition of the study sample was prepared at the Nutrition

\section{RESULTS AND DISCUSSION}

In developing 5 recipes shown in Table 1, we used wheat, barley, rye, peas, rapeseed cake, bone flour, and mineral premix as raw for young pigs and to determine its impact on pork output and productivity of pigs. The novelty of the study lies in the possibility of developing premixed recipe with a balanced mixture of raw materials produced exclusively in the country.
Assessment Laboratory of the Research Institute of Animal Husbandry. The defining methods were: Humidity and ashes by weight method (MNS 6548:2015), proteins by Kjeldahl method (MNS 6549:2015), fiber and its fractions by ANKOM method (MNS 6551:2015), fats by Soxhlet method (MNS 6554:2015), macro-microelements (MNS 4655:2015) by standard method, and exchange energy by calculation method [1].

Table 1. Composition of test diets (dry matter basis)

\begin{tabular}{lccccccc}
\hline \multicolumn{1}{c}{ Items } & & $\begin{array}{c}\text { Control } \\
\text { group }\end{array}$ & $\begin{array}{c}\text { Group } \\
\text { I }\end{array}$ & $\begin{array}{c}\text { Group } \\
\text { II }\end{array}$ & $\begin{array}{c}\text { Group } \\
\text { III }\end{array}$ & $\begin{array}{c}\text { Group } \\
\text { IV }\end{array}$ & $\begin{array}{l}\text { Group } \\
\text { V }\end{array}$ \\
\hline Mineral Premix & $\mathrm{kg}$ & $\underline{0}$ & $\underline{2.0}$ & $\underline{3.0}$ & $\underline{4.0}$ & $\underline{5.0}$ & $\underline{6.0}$ \\
Wheat & $\mathrm{kg}$ & 55 & 55 & 54 & 53 & 52 & 51 \\
Barley & $\mathrm{kg}$ & 30 & 30 & 30 & 30 & 30 & 30 \\
Wheat bran & $\mathrm{kg}$ & 5.0 & 4.0 & 4.0 & 4.0 & 4.0 & 4.0 \\
Peas & $\mathrm{kg}$ & 3.0 & 4.0 & 4.0 & 4.0 & 4.0 & 4.0 \\
Rapeseed cake & $\mathrm{kg}$ & 6.0 & 3.0 & 3.0 & 3.0 & 3.0 & 3.0 \\
Bone flour & $\mathrm{kg}$ & 1.0 & 2.0 & 2.0 & 2.0 & 2.0 & 2.0 \\
Total & $\mathrm{kg}$ & 100 & 100 & 100 & 100 & 100 & 100 \\
\hline
\end{tabular}

In order to fully detect the effect of the concentrators and to compare the results, we tried to include in the recipes the same amount from the main raw materials and did not change materials, which are easily available in Mongolia at a cheap rate and which have a high quality appropriate for young pig feed. the main raw materials due to the nutrition of the concentrators, but variably added the premix at a ratio of 2-6 per cent. 
Table 2. Chemical composition of raw materials

\begin{tabular}{lcccc}
\hline Item & Protein $(\%)$ & Fat (\%) & Fiber & Ash (\%) \\
\hline Wheat & $15.5 \pm 0.62^{\mathrm{ab}}$ & $2.2 \pm 0.72^{\mathrm{ab}}$ & $3.2 \pm 1.11^{\mathrm{a}}$ & $4.8 \pm 0.45^{\mathrm{ab}}$ \\
Wheat bran & $9.30 \pm 0.25^{\mathrm{b}}$ & $3.8 \pm 0.32^{\mathrm{a}}$ & $11 \pm 0.26^{\mathrm{ab}}$ & $5.2 \pm 0.15^{\mathrm{ab}}$ \\
Barley & $11.9 \pm 0.78^{\mathrm{a}}$ & $1.5 \pm 1.02^{\mathrm{a}}$ & $9.5 \pm 0.19$ & $1.8 \pm 0.36^{\mathrm{a}}$ \\
Peas & $26.5 \pm 0.95^{\mathrm{ab}}$ & $1.2 \pm 0.45^{\mathrm{a}}$ & $7.5 \pm 0.64^{\mathrm{a}}$ & $2.8 \pm 0.55^{\mathrm{a}}$ \\
Rapeseed cake & $25.5 \pm 0.54^{\mathrm{ab}}$ & $5.4 \pm 0.21^{\mathrm{ab}}$ & $4.1 \pm 0.57^{\mathrm{a}}$ & $5.8 \pm 1.78^{\mathrm{ab}}$ \\
Rye & $12.5 \pm 0.45^{\mathrm{a}}$ & $2.4 \pm 0.38^{\mathrm{a}}$ & $5.4 \pm 0.66^{\mathrm{a}}$ & $2.6 \pm 0.70^{\mathrm{a}}$ \\
\hline
\end{tabular}

We can be see from Table 1 that the developed recipes meet the daily norm of nutrients for young pigs. So we used it for testing pork productivity effects. In grain raw materials of the recipes, there are 9.32-26.5 per cent of total protein, 1.2-5.4 per cent of total fat, 3.2-11 per cent of total fiber, and 1.8-5.8 per cent of total ash.

Table 3. Chemical composition of premixed recipe, in dry air, \% (dry matter basis)

\begin{tabular}{lccccc}
\hline \multicolumn{1}{c}{ Item } & Protein $(\%)$ & Fat $(\%)$ & Fiber & Ash (\%) \\
\hline Control group & 15.8 & 3.5 & 6.1 & 5.4 \\
Mineral Premix & $2 \%$ & 20.1 & 3.8 & 6.5 & 6.1 \\
Mineral Premix $3 \%$ & 17.8 & 3.5 & 6.1 & 6.5 \\
Mineral Premix $4 \%$ & 19.0 & 4.0 & 6.8 & 5.9 \\
Mineral Premix & $5 \%$ & 19.8 & 4.1 & 5.5 & 6.7 \\
Mineral Premix $6 \%$ & 19.8 & 4.0 & 6.7 & 6.5 \\
\hline
\end{tabular}

As Table 2 shows, the normal functioning of an animal requires an appropriate amount of nutrients, which must contain the necessary energy required for the normal functioning of cells and organs. The necessary energy is obtained from nutrients, which are used for normal functioning of the body and for higher productivity.

Total protein and fiber content of the 5 premixed recipes are 17.8-20.1 and 5.5-6.5 respectively. This is because the main ingredients of the recipes are generally made from the same raw materials.

Table 4. Digestion rate of the recipes' nutrient ingredients

\begin{tabular}{llcc}
\hline Item & Digestion rate of organics, \% & Exchange energy, MDj \\
\hline Control group & 83.1 & 8.8 \\
Mineral Premix & 2\% & 86.6 & 9.2 \\
Mineral Premix & $\% \%$ & 85.7 & 9.1 \\
Mineral Premix & 4 \% & 88.7 & 9.5 \\
Mineral Premix & $5 \%$ & 90.2 & 9.6 \\
Mineral Premix & $6 \%$ & 90.1 & 9.8 \\
\hline
\end{tabular}

Table 3 shows that the chemical composition of the feeds of the control and experimental groups are quite similar to each other, and that the feeds of young pigs are nutritious enough to meet their daily norm.
The exchange energy of the premixed control group feed recipes was $8.8 \mathrm{MDj}$, while the exchange energy of the experimental group was 9.1-9.8 MDj. 
The exchange energy of the experiment group, which had 5 per cent of premix, was 9.8 $\mathrm{MDj}$. If we see the digestion rate of organics, the digestion rate of premixed control group feed recipes was 83.1 per cent, while the digestion rate of the experimental groups was 88.7-90.2 per cent. This means that the nutrition of the feed for experimental groups is higher than of the control group.

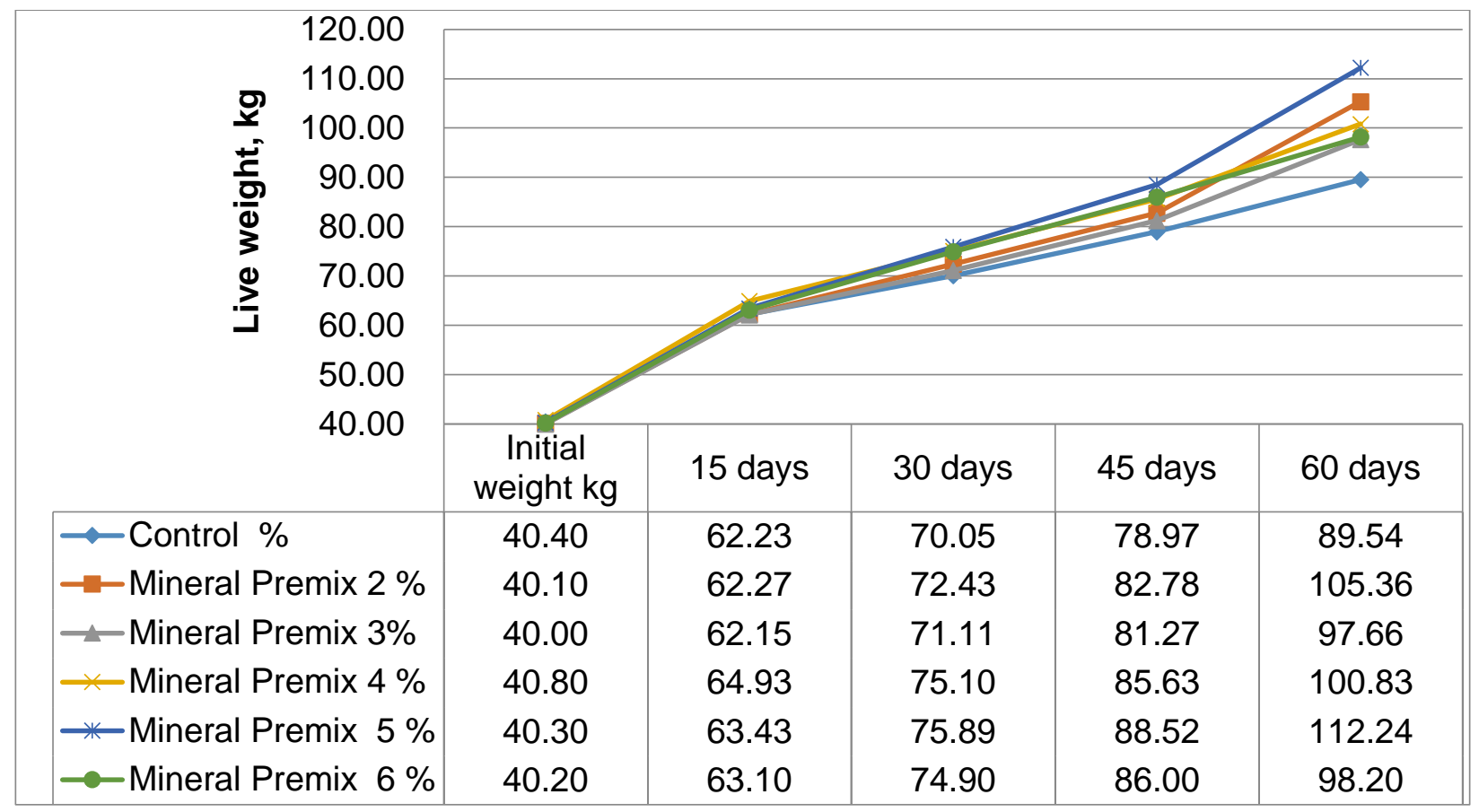

Figure 1. Impact of premix on live animal weight

Figure 1 shows that the control group, which was fed with the recipe without premix, grew $35.9 \mathrm{~kg}$ or 1.8 times the original weight, but the experiment groups, which were fed with the recipe with 2-6 per cent premix grew 44.7-
$59 \mathrm{~kg}$ or 2.1-2.4 times their weight, respectively.

In the early stages of growth, it was more effective to increase the live weight by 2.4 times, which means that adding 5 per cent premix in the main recipe was very efficient.

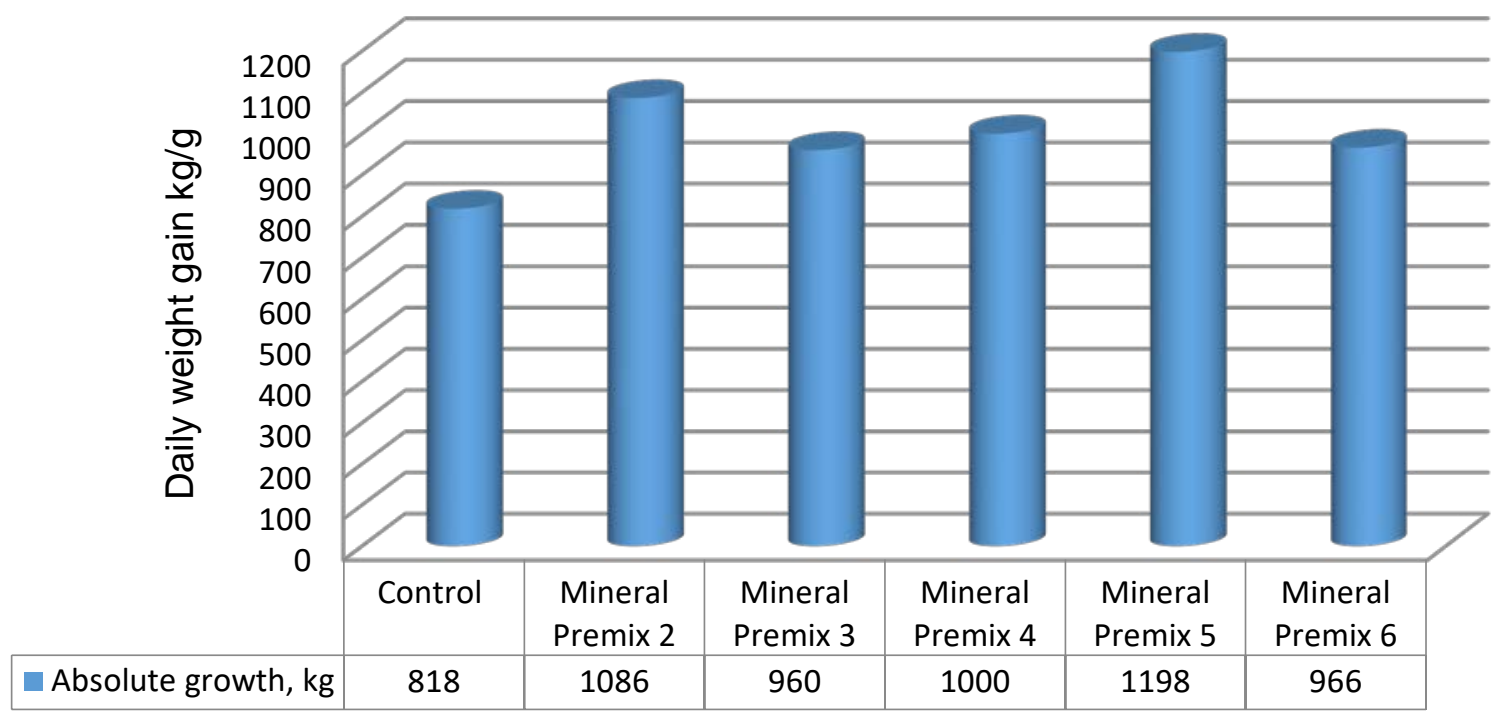

Figure 2. Daily weight gain of feed ration enriched with mineral premix 
When we tested full-formula, enriched with mineral premix feed recipe, the recipe with 5 per cent full formula gave an increase of $987 \mathrm{~g}$ weight per day and 79 per cent relative growth, which was higher by 70-238g weight per day and more by 5-22.9 per cent relative growth than other recipes.

If we compare the chemical component of the wheat used for most of the mixed feed of young pigs with the results of the studies conducted by other researchers, we find there is 35 gram less protein and 3.1 grams of fiber less than the research conducted by P. Tumenbayar, B. Bolor-Erdene, N. ogtohbayar, and Kh. Gendaram (2008), 28 grams of protein more and 19 grams of fiber less than the research by D. Gurbazar (2015), while this figure for protein was less by 2.2 per cent, fiber by 0.6 per cent and fat by 0.5 per cent in the studies conducted by N.Togtohbayar, Kh. Gendaram, Ch. Sodnomtseren, and A. Otgonjargal [3].

Mixed feed developed by Kh. Gendaram, N. Togtokhbayar, Ch. Sodnomtseren and A. Otgonjargal with 25 per cent bran, 20 per cent wheat, 10 per cent barley, 15 per cent oatmeal, 5 per cent meat flour, 22 per cent grass, 2 per cent bone flour and 1 per cent mineral

\section{CONCLUSIONS}

Adding premix of 5 per cent in mixed feed recipes for young pigs resulted in 90.2 per cent increase in the digestion rate of organics of the recipe, which is more than 7.1 per cent from the control group and 1.4-4.3 per cent from other variations

\section{REFERENCES}

1. Gendaram Kh., Togtokhbayar N., Rinchindorj D. (2009). Chemical analyzing methods of feeds and meat. UB.

2. Gendaram Kh. (2009). Wisdom of feeding animanls. UB.

3. Gendaram Kh., Togtokhbayar N., Otgonjargal A. (2005). Evaluating nutrients of the feed by excgange energy. UB.

4. Richard O., Kellems D., Church C. Livestock Feeds \& Feeding. supplement mixed feed contains 5.65 per cent of protein and a total of 2.4 per cent more fat and 3.21 per cent less fiber than the mixed feed developed by us [3].

R. Burenbayar conducted a 60-day experiment of mixed feed for young pigs putting 81 pigs in 6 groups. The mixed feed included barley, wheat, oat, peas, and bran making up 74 per cent of the components, tankage 6 per cent, feed yeast 6 per cent, and mineral premix 1 per cent. During the experiment, weight gain was $22 \mathrm{~kg}$ per experiment day, which is $1.8 \mathrm{~kg}$ more than the control recipe [6] .

Furthermore, when recipe of the mixed feed for meat pigs contained 1 per cent mineral premix, 34 per cent barley, 14 per cent bran, 40 per cent wheat, 2.5 per cent peas, 2.5 per cent feed yeast, 3.0 per cent vitamin grass flour, and 1 per cent bone meal, the daily weight gain was $498 \mathrm{~g}$, and $310 \mathrm{~g}$ for control [6] respectively.

Organic matter digestibility of the recipe containing 1-4 per cent premix was 75 per cent, total protein was 76.9 per cent, meanwhile the digestibility of the recipe we studied was 8390.1 per cent, total protein was 69 per cent, fat i67-69, and fiber was 32.2 per cent [6].

Increasing primex upto 5 per cent helps increase daily growth of young pigs by 984.99 g, slaughter output by 79.93 per cent and reduces the thickness of fat by $0.9 \mathrm{~cm}$.

5. Burenbayar R. (1990). Report on method developing for balancing of the ration of pig feeds. UB.

6. Decision-making on the use of diverse combinations of agricultural products and natural plants in pig feed: a case study of native pig smallholder in northern Thailand SpringerLink. https://link.springer.com/article/10.10 07/s11250-007-9081-6. Accessed April 24, 2019. 
7. González-Vega JC, Stein HH. - invited review - calcium digestibility and metabolism in pigs. Asian-Australas J Anim Sci. 2014;27(1):1-9. doi:10.5713/ajas.2014.r.01Do SH, Kim BO, Fang LH, You DH, Hong J su, Kim YY. Various levels of rapeseed meal in weaning pig diets from weaning to finishing periods. Asian-
Australas J Anim Sci. 2017;30(9):1292-1302.

doi:10.5713/ajas.16.095.

8. S Van Der Linden, PR Kenyon, HT Blair, N Lopez-Villalobos, CMC Jenkinson, SW Peterson, DDS Mackenzie performance of offspring at their first lactation. Asian-Australas J Anim Sci2009(12)3944-3954. 